Results and discussion. The data showing the effect of EMS on different types of spermatogonia are given in the table. At the dose of $100 \mathrm{mg} / \mathrm{kg}$, only a small fraction of all A types, In and B spermatogonia were reduced by 3 days after EMS administration. At higher doses (300 and 400 $\mathrm{mg} / \mathrm{kg}$ ) all types of spermatogonia were affected within $24 \mathrm{~h}$ with maximum killing of $\mathrm{A}_{1}-\mathrm{A}_{4}$ cells. Highly profound depletion $(96 \%)$ in Pl cells, 3 days after administration of 300 and $400 \mathrm{mg} / \mathrm{kg}$, reflected killing of a large fraction of $\mathrm{A}_{4}$ and In spermatogonia. Similarly $97 \%$ decrease in the number of $\mathrm{B}$ cells, 3 days after treatment with the same doses indicates damage of late $A_{3}$ and early $A_{4}$ cells, since spermatogenesis is a dynamic process, the cell-types scored are different from the cell types treated. Although EMS was found to affect most of the types of differentiating spermatogonea, all the cells are not uniformly killed.

EMS increases the incidence of dominant lethals in the post meiotic phase of spermatogenesis largely affecting the spermatids and the sperms ${ }^{8-11}$. EMS has also recently been reported to induce in vivo somatic mutation in mice at relatively lower dosage levels of 50 and $100 \mathrm{mg} / \mathrm{kg}^{12}$. However, $300 \mathrm{mg} / \mathrm{kg}$ of EMS has failed to increase the mutation frequency in the specific locus test in the mouse spermatogonia ${ }^{13}$. The present study shows that EMS is capable of inflicting biological damage in the premeiotic phase and affects the various spermatogonial cells in a differential manner.
1 E.F. Oakberg, Anat. Rec. 169, 515 (1971)

2 E. F. Oakberg, Mutat. Res. 11, 7 (1971).

3 C. Huckins, Anat. Rec. 169, 533 (1971).

4 E.F. Oakberg, in: Physiology of Reproduction, p. 197. Ed. E.M. Coutinho and F. Fuchs. Plenum Press, New York 1974.

5 D. Bhattacharjee and M. V. Narurkar, Proc. Symp. Mutagenicity, Carcinogenicity and Teratogenicity of Chemicals, p.56. Dept. of Atomic Energy, Bombay, India 1975.

6 D. Bhattacharjee, T.K. Shetty and K. Sundaram, 2nd int. Conf. environm. Mutagen, Edinburgh 1977, abstr.
7 D.. Bhattacharjee, T.K. Shetty and K. Sundaram, 3rd Ann. Meet. environm. Mutagen Soc. India 1978, abstr.

8 B.M. Cattanach, C.E. Pollard and J.H. Isaacson, Mutat. Res. 6, 297 (1968).

9 U.H. Ehling, R.B. Cumming and M.V. Malling, Mutat. Res. 5, 417 (1968)

10 W.M. Generoso and W. L. Russell, Mutat. Res. 8, 589 (1969)

11 M. Partington and H. Jackson, Genet. Res. 4, 333 (1963).

12 L. B. Russell, Archs Toxic. 38, 75 (1977).

13 U.H. Ehling and W.L. Russell, Genetics 61, 14 (1969).

\title{
Comparative studies on the covalent binding of the carcinogen benzo(a)pyrene to DNA in various model systems ${ }^{1}$
}

\author{
W. Jaggi, W. K. Lutz and Ch. Schlatter ${ }^{2}$ \\ Institute of Toxicology, Federal Institute of Technology and University of Zurich, CH-8603 Schwerzenbach (Switzerland), \\ 10 January 1979
}

Summary. The covalent binding of tritiated benzo(a)pyrene (BP) to DNA has been determined in rat liver in vivo, in rat liver perfused in situ, after incubation of BP with liver single cells, with liver homogenate, with liver microsomes and DNA, with fibroblasts from a rat granuloma pouch, and with 2 cell lines. Liver single cells were found to be a valuable compromise between the most sensitive system (microsomal incubation of BP with DNA) and the biologically most relevant system (in vivo).

It is now widely accepted that the first step in the chemical induction of a tumour involves binding of the chemical or one of its metabolites to a biological macromolecule ${ }^{3}$. Good correlations between that binding and carcinogenicity have been found particularly with DNA as target molecules $^{4}$. Before such a binding can occur most substances have first to be converted by enzymatic action to reactive metabolites ${ }^{5}$. Only a very small fraction reacts with nucleic acids so that this type of binding can normally be measured only by using radiolabelled chemicals. Because of the cost of radioactive compounds and the limited availability of high specific activities, the yield of chemical bound to DNA as a fraction of the total amount of chemical used should be optimized so that a radioactivity on DNA can be measured from a minimal dose administered.

We have measured the binding of a standard carcinogen (tritiated benzo(a)pyrene, BP) to DNA in various model systems and have calculated the specific binding of BP per mg DNA as well as the radioactivity which can be recovered in a scintillation vial from the total DNA isolated. This comparison will help to choose the most appropriate model system for measuring the binding of other suspected carcinogens to DNA.

Materials and methods. Chemicals. Inactive BP was obtained from Fluka AG, Buchs, Switzerland. Generally tritiated BP (purified on silica-gel before use) was from the Radiochemical Centre, Amersham, England, $36 \mathrm{Ci} / \mathrm{mmole}$. NADP, glucose-6-phosphate and glucose-6-phosphatedehydrogenase were from Boehringer, Mannheim, GFR.
The other reagents used were of the purest grade available from Merck, Darmstadt, GFR.

Isolation of DNA. DNA was isolated according to Markov and Ivanov ${ }^{6}$ with the modifications described before ${ }^{7}$.

Rat liver, in vivo. $0.5 \mathrm{ml}$ of a BP solution in oil was given to male rats (SIV 50, Sprague-Dawley derived, about $300 \mathrm{~g}$ ) by i.p. injection ( $4 \mathrm{mg}, 10^{9} \mathrm{dpm}$ ). After $50 \mathrm{~h}$, the liver was excised and DNA was isolated.

Liver perfusion in situ. Female rats $(250 \mathrm{~g})$ were given $60 \mathrm{mg} / \mathrm{kg}$ pentobarbitone and the liver was perfused in situ for $2 \mathrm{~h}$ by cannulation of the portal vein (in) and the thoracic portion of the vena cava (out). Tritiated BP $(0.6 \mu \mathrm{g}$, $1.83 \cdot 10^{8} \mathrm{dpm}$ ) was deposited on the bottom of a $25 \mathrm{ml}$ conical flask by evaporating the hexane from the stock solution under a stream of nitrogen and $20 \mathrm{ml}$ of perfusion buffer $\left(0.8 \% \mathrm{NaCl}, 0.04 \% \mathrm{KCl}, 0.005 \% \quad \mathrm{Na}_{2} \mathrm{HPO}_{4}, 0.006 \%\right.$ $\mathrm{KH}_{2} \mathrm{PO}_{4}, \mathrm{pH} 7.6$ with $\mathrm{NaOH}$ ) was added. Oxygen was supplied by keeping the perfusion buffer reservoir at $37^{\circ} \mathrm{C}$ under oxygen. The blood present in the liver at the beginning of the perfusion was included in the closed circuit in order to solubilize the BP.

Liver single cells. Single cells were prepared after perfusion of a rat liver with a solution of collagenase ${ }^{8}$. BP $(0.73 \mu \mathrm{g}$, $2.05 \cdot 10^{8} \mathrm{dpm}$ ) was added to a $25 \mathrm{ml}$ conical flask as described above and the cells were incubated for $3 \mathrm{~h}$ at $37^{\circ} \mathrm{C}$ in Hanks' solution.

Liver homogenate. Rat liver was treated in a loose-fitting Potter-Elvehjem homogenizer with a teflon pestle in 3 vol. of buffer (0.25 M sucrose, $0.01 \mathrm{M}$ Tris $/ \mathrm{HCl}, \mathrm{pH}$ 7.4). The 
homogenate (about $30 \mathrm{ml}$ ) was incubated under oxygen in a $300 \mathrm{ml}$ conical flask, prepared with BP $\left(11 \mu \mathrm{g}, 3.7 \cdot 10^{8}\right.$ $\mathrm{dpm})$ as above, in a shaking water-bath at $37^{\circ} \mathrm{C}$, and aliquots were taken for the isolation of DNA.

Liver microsomes incubated with DNA. Microsomes were prepared according to Schenkman and $\mathrm{Cinti}^{9}$ with modifications described elsewhere ${ }^{10}$. The incubation mixture consisted of $50 \mathrm{mM}$ Tris/ $\mathrm{HCl}, \mathrm{pH} 7.5,2.5 \mathrm{mM} \mathrm{KCl}, 5 \mathrm{mM}$ $\mathrm{MgCl}_{2}, 2.5 \mathrm{mM}$ glucose-6-phosphate, $1 \mathrm{mM}$ NADP, $1 \mathrm{U} / \mathrm{ml}$ glucose-6-phosphate-dehydrogenase, $0.7-2.2 \mu \mathrm{g} \mathrm{BP}$, $0.64-3.66 \mathrm{mg}$ DNA and had a total volume of $4 \mathrm{ml}$. The incubation was performed in a $25 \mathrm{ml}$ conical flask at $37^{\circ} \mathrm{C}$ in a shaking water-bath for $90 \mathrm{~min}$.

A control incubation of BP with DNA and the cofactor system but without microsomes gave rise to the appreciable binding of $190 \mathrm{dpm} / \mathrm{mg}$ per $10^{7} \mathrm{dpm}$ (3 experiments). This radioactivity was not extractable from DNA with ethanol and ether. This nonenzymatic binding is in agreement with earlier reports ${ }^{11}$, where a covalent binding depending on time, light and temperature was also found.

Fibroblasts from rat granuloma pouch. Fibroblasts were prepared in Petri dishes (8 $\mathrm{cm}$ diameter) according to Maier et al. ${ }^{12}$. BP $\left(8 \mu \mathrm{g}, 2.1 \cdot 10^{9} \mathrm{dpm}\right)$ in acetone (final concentration $0.07 \%$ ) was added to the culture medium when the cells had reached confluency. After 12 or $24 \mathrm{~h}$, this medium was substituted by the lysing medium used for the first step of the DNA isolation procedure ${ }^{6}$ and the cells were collected from the dishes with a scalpel.

Cell lines. Rabbit cornea (SIRC) and monkey kidney (VERO) cells were grown to confluency in $7 \times 10 \mathrm{~cm}$ culture bottles. The medium was decanted into a conical flask, the bottom of which was covered with radioactive BP $\left(0.08-0.4 \mu \mathrm{g}, 0.215-1.08 \cdot 10^{8} \mathrm{dpm}\right)$. After dissolving the BP by shaking for $10 \mathrm{~min}$ at $37^{\circ} \mathrm{C}$, the medium was poured back into the culture bottles and the cells were incubated for $4 \mathrm{~h}$. The medium was removed, lysing medium (Markov and Ivanov $^{6}$ ) was added and the cells were scratched loose with a rubber scraper.

Results and discussion. Averaged results obtained from the different systems are compiled in the table. Column 1 with the specific binding shows that the amount of benzo(a)pyrene bound per mg DNA varies by more than 3 orders of magnitude between the 2 extreme systems, in vivo and

Binding of tritiated benzo(a)pyrene to DNA in various model systems

\begin{tabular}{|c|c|c|c|}
\hline System & $\begin{array}{l}\text { Specific binding } \\
\mathrm{dpm} / \mathrm{mg} \mathrm{DNA} \\
\text { per } 10^{7} \mathrm{dpm} \\
\text { administered. }\end{array}$ & $\begin{array}{l}\text { Total } \\
\text { yield } \\
\text { of DNA } \\
\text { (mg) }\end{array}$ & $\begin{array}{l}\text { dpm available } \\
\text { on total DNA } \\
\text { from } 10^{7} \mathrm{dpm} \\
\text { administered }\end{array}$ \\
\hline $\begin{array}{l}\text { Rat liver, in vivo } \\
\text { Liver perfusion } \\
\text { Liver single cells }\end{array}$ & $\begin{array}{c}1.6 \pm 0.6 \cdot(3) \\
5 \pm 2(2) \\
220 \pm 40(3)\end{array}$ & $\begin{array}{l}10 \\
8 \\
0.5\end{array}$ & $\begin{array}{r}16 \\
40 \\
100\end{array}$ \\
\hline $\begin{array}{l}\text { Liver homogenate } \\
\text { 1-hour incubation } \\
\text { 2-hour incubation }\end{array}$ & $\begin{array}{l}7 \\
9\end{array}$ & $\begin{array}{l}4 \\
4\end{array}$ & $\begin{array}{l}30 \\
40\end{array}$ \\
\hline $\begin{array}{l}\text { Liver microsomes } \\
\text { incubated with DNA }\end{array}$ & $2600^{*}$ & 0.2 & 520 \\
\hline $\begin{array}{l}\text { Fibroblasts } \\
\text { 12-hour incubation } \\
\text { 24-hour incubation }\end{array}$ & $\begin{array}{l}280 \\
240\end{array}$ & $\begin{array}{l}0.07 \\
0.06\end{array}$ & $\begin{array}{l}19 \\
14\end{array}$ \\
\hline $\begin{array}{l}\text { Rabbit cornea } \\
\text { cell line (SIRC) }\end{array}$ & $1400 \pm 600(3)$ & 0.11 & 150 \\
\hline $\begin{array}{l}\text { Monkey kidney } \\
\text { cell line (VERO) }\end{array}$ & $850 \pm 600(3)$ & 0.12 & 100 \\
\hline
\end{tabular}

The SD and the number of determinations is given if applicable. * With optimal conditions $(0.74 \mu \mathrm{g} \mathrm{BP}, 0.64 \mathrm{mg}$ DNS, $0.53 \mathrm{mg}$ microsomal protein); see 'Materials and methods'. incubation of BP with DNA in the presence of microsomes. Liver perfusion and liver homogenate yield a specific binding which is only slightly larger than the one found with the intact animal. There is therefore no real advantage in choosing one of these systems since the lower sensitivity of the in vivo experiment is more than compensated by the advantage of having an intact organism as well as by the fact that other organs beside the liver can simultaneously be analyzed.

The cellular systems investigated differ substantially from each other and the cell lines revealed a large variability between single experiments, which is probably due to changes in the activating enzyme systems. The experiments with the liver single cells showed a remarkably small variability and a high specific binding. This system therefore represents a valuable compromise between the in vivo experiment and the microsomal incubation with respect to sensitivity, reproducibility and biological relevance.

The specific binding discussed so far gives a measure of how many molecules BP are bound per mg DNA; it can be used for choosing the most appropriate system for studies on the chemical nature of the BP-nucleotide adduct where it is important to have a maximal fraction of modified nucleotides.

If, however, the question is whether a chemical binds to DNA at all, the amount of DNA which can be obtained from the different systems is also important, since the more DNA can be brought into a scintillation vial, the better is the limit of detection for a bound radioactive molecule. This yield of DNA is given in column 2 of the table and is shown to vary by a factor of 100 . A multiplication of the values of column 1 and 2 results in the radioactivity expected on the total DNA from an experiment with $10^{9} \mathrm{dpm}$ starting activity (column 3 ). Thanks to the high yield of DNA from the experiments with low specific binding (in vivo, perfusion, homogenate), the various model systems differ only by a factor of about 30 with respect to the limit of detection, and the liver single cells are only 5 times less sensitive than the microsomal incubation.

Based upon the values in column 3 and the biological relevance of the different systems, preference will be given generally to the in vivo experiment. However, if the amount of radioactivity available is a very limiting factor, liver single cells can be recommended or, for structural analysis of DNA-bound compounds, an incubation of DNA in the presence of microsomes.

1 Presented in part at the 10th Annual Meeting of the Union of Swiss Societies of Experimental Biology, Experientia 34, 925 (1978), abstract.

2 Acknowledgment. We thank Dr G. Kistler, Institute of Anatomy, University of Zurich, for generously supplying the SIRC and VERO cell lines, and Mr P. Manser for the preparation of the granuloma pouch fibroblasts.

3 C. Heidelberger, A. Rev. Biochem. 44, 79 (1975).

4 P. Brookes, in: Biological reactive intermediates, p. 470 . Ed. D. J. Jollow. Plenum Press, New York and London 1977.

5 J.A. Miller, Cancer Res. 30, 559 (1970).

6 G.G. Markov and I.G. Ivanov, Analyt. Biochem. 59, 555 (1974).

7 W.K. Lutz, A. Viviani and Ch. Schlatter, Cancer Res. 38, 575 (1978).

8 M. N. Berry and D.S. Friend, J. Cell Biol. 43, 506 (1969).

9 J.B. Schenkman and D. L. Cinti, Life Sci. 11, 247 (1972)

10 A. Viviani, W. K. Lutz and Ch. Schlatter, Biochem. Pharmac. 27, 2103 (1978).

11 S. Grilli, P. Rocchi and P. Prodi, Chem. biol. Interact. 11, 351 (1975).

12 P. Maier, P. Manser and G. Zbinden, Mutat. Res. 54, 159 (1978). 